\title{
Modulation of Immune Biomarkers by Biofield Energy Healing Based Herbomineral Formulation in Male Sprague Dawley Rat: Potential Role of Energy of Consciousness
}

\author{
Mahendra Kumar Trivedi ${ }^{1}$, Alice Branton ${ }^{1}$, Dahryn Trivedi ${ }^{1}$, Gopal Nayak ${ }^{1}$, Alan Joseph Balmer ${ }^{1}$, \\ Dimitrius Anagnos', Janice Patricia Kinney ${ }^{1}$, Joni Marie Holling ${ }^{1}$, Joy Angevin Balmer ${ }^{1}$, \\ Lauree Ann Duprey-Reed ${ }^{1}$, Vaibhav Rajan Parulkar', Mayank Gangwar², Snehasis Jana ${ }^{2}$, * \\ ${ }^{1}$ Trivedi Global, Inc., Henderson, USA \\ ${ }^{2}$ Trivedi Science Research Laboratory Pvt. Ltd., Bhopal, India
}

Email address:

publication@trivedieffect.com (S. Jana)

${ }^{*}$ Corresponding author

To cite this article:

Mahendra Kumar Trivedi, Alice Branton, Dahryn Trivedi, Gopal Nayak, Alan Joseph Balmer, Dimitrius Anagnos, Janice Patricia Kinney, Joni Marie Holling, Joy Angevin Balmer, Lauree Ann Duprey-Reed, Vaibhav Rajan Parulkar, Mayank Gangwar, Snehasis Jana. Modulation of Immune Biomarkers by Biofield Energy Healing Based Herbomineral Formulation in Male Sprague Dawley Rat: Potential Role of Energy of Consciousness. Advances in Bioscience and Bioengineering. Vol. 5, No. 6, 2017, pp. 96-106. doi: 10.11648/j.abb.20170506.12

Received: October 30, 2017; Accepted: November 11, 2017; Published: November 11, 2017

\begin{abstract}
The present study aimed to evaluate the impact of The Trivedi Effect ${ }^{\circledR}$ - Energy of Consciousness Healing Treatment based new proprietary herbomineral formulation and Energy Healing Treatment per se in male Sprague Dawley rats for immune biomarkers modulation. The test formulation was divided into two parts, one as the control without any Biofield Energy Treatment, while the other part was defined as the Biofield Energy Treated sample, which received the Biofield Energy Healing Treatment remotely from seven renowned Biofield Energy Healers. Additionally, one group of animals also received Biofield Energy Treatment per se (day -15) by under similar conditions. Humoral immune response data showed an increased level of IgG by $2.89 \%, 6.20 \%$, and $6.20 \%$ in the Biofield Energy Treated test formulation group (G4), Biofield Energy Treatment group per se (G6), and Biofield Energy Treated test formulation at day -15 (G7), respectively as compared with the disease control group (G2). The ratio of $\mathrm{CD}^{+} / \mathrm{CD}^{+}$was increased by $3.80 \%, 12.38 \%$, and $16.19 \%$ in the G4, G6, and G7, respectively compared with the G2. Hematology analysis suggested an increased level of TLC and neutrophil by $9.64 \%$ and $1.48 \%$, respectively in the G4 group, while G6 group showed an increase count of TLC, lymphocytes, and monocytes by $19.79 \%, 2.87 \%$, and $15.54 \%$, respectively compared with the G2. Biochemical study showed an increased concentration of glucose by $11.78 \%, 18.60 \%$, and $56.84 \%$ in the G4, G6, and G7, respectively compared with G2. Total cholesterol was significantly decreased by $10.54 \%$ and $4.20 \%$ in the G4 and G7, respectively compared with G2. In contrast, the HDL level was increased by $11.69 \%$ and $1.06 \%$ in G6 and G7, respectively while LDL was decreased by $10.52 \%$ in G4 compared with the G2. SGOT, CK-MB, total protein, albumin, and globulin levels were decreased by $4.04 \%, 23.54 \%, 1.68 \%, 1.54 \%$, and $1.80 \%$, respectively in G4, while G6 group showed decreased level of SGOT, CK-MB, and A/G ratio by $2.08 \%, 16.23 \%$, and $3.40 \%$, respectively compared with G2. However, SGOT was significantly decreased $(p \leq 0.01)$ by $18.88 \%$ in G7 compared with G2. The testosterone level was decreased by $76.67 \%, 18.43 \%$, and $44.06 \%$ in G4, G6, and G7, respectively compared with G2. Antioxidant profile showed a decreased level of LPO by $59.63 \%$ in G7, while SOD and CAT levels were significantly altered in tested groups compared with G2. Biofield Energy may also be used for autoimmune and inflammatory diseases, stress management and prevention, and anti-aging by improving overall health.
\end{abstract}

Keywords: Biofield Energy Healing Treatment, Consciousness Energy Healing Treatment, The Trivedi Effect ${ }^{\circledR}$, Herbomineral Formulation, Anti-oxidation, Autoimmunity, Anti-Aging, Alzheimer's Disease 


\section{Introduction}

Herbomineral products have been accepted worldwide against many health related disorders, due to their significant immunomodulatory potential. However, the action of herbominerals as an immune booster make it unique as compared with other available nutraceutical products. Overall quality of life (QoL) can be improved by maintaining the organic resistance of the body. It was reported that secondary metabolites of plants extract and minerals play an important role in immunomodulatory action [1-3]. Herbal medicines and minerals are the major targeted product to modulate the immune system due to its low toxicity profile compared with the synthetic drugs against infections $[4,5]$. However, as a conventional approach, immunomodulatory therapy has now been considered as primary treatment in many disease conditions. To predict the severity of infection and evaluating the therapeutic immunomodulatory potential of any herbomineral formulations, biomarkers with respect to hepatic, cardiac, lipid, hematology, cellular and humoral response are considered as the standard method of analysis [6]. According to the scientific literatures, and as per the best medicinal activity of herbal extract, a new proprietary herbomineral formulation was formulated with a combination of the herb ashwagandha (Withania somnifera) root extract and three minerals viz. zinc, magnesium, and selenium. All the ingredients of the formulation in this present study possess important activities such as immune-modulatory, anti-inflammatory, antioxidant, anti-infective, and anti-viral properties [7-9].

Ashwagandha biological activity is mainly reported due to the presence of withanolides, and it is used as complementary medicine in alternative therapies. Apart from its common attributes such as antibacterial, immunomodulatory and antitumor effects, many clinical and preclinical data have been available with respect to the immunomodulatory impact $[10,11]$. The importance of minerals such as selenium, zinc, and magnesium is to modulate the immune system because their synergistic impact has been well-defined. Zinc regulates most of the biochemical reaction in the living organism because of enzyme catalyzing activity, while selenium work as significant immunomodulatory effect by altering the $\mathrm{CD}^{+}$ lymphocyte function. Similarly, magnesium is also responsible for cytokine production through NF- $\mathrm{KB}$ pathways activation, a novel innate immunomodulatory mechanism [12-15].

Scientific research has been reported that the combination of minerals and herbal medicines have been found to exhibit significant immunomodulatory action [5]. Herbomineral formulations can be used for better therapeutic effect in immune compromised patients that are affected by the cardiovascular diseases, age, stress related diseases, cancer, and autoimmune disorders. Along with the herbomineral formulations, the Biofield Energy Healers in this study have used Energy Medicine (Biofield Energy Healing Treatment) as a complementary and alternative approach to study the impact of the Biofield Energy Treatment on the herbomineral formulation for its immunomodulatory potential in male Sprague Dawley rats.

Amidst many Complementary and Alternative Medicine (CAM) therapies, there have been an extensive number of scientific reports that showed Biofield Therapy (or Healing Modalities) as preferred models of treatment with several benefits to enhance physical, mental and emotional human wellness. The National Center of Complementary and Integrative Health (NCCIH) has recognized and accepted Biofield Energy Healing as a CAM health care approach in addition to other therapies, medicines and practices such as natural products, deep breathing, yoga, Tai Chi, Qi Gong, chiropractic/osteopathic manipulation, meditation, massage, special diets, homeopathy, progressive relaxation, guided imagery, acupressure, acupuncture, relaxation techniques, hypnotherapy, healing touch, movement therapy, pilates, Rolfing structural integration, mindfulness, Ayurvedic medicine, traditional Chinese herbs and medicines, naturopathy, essential oils, aromatherapy, Reiki, and cranial sacral therapy. Human Biofield Energy has subtle energy that has the capacity to work in an effective manner [16]. CAM therapies have been practiced worldwide with reported clinical benefits in different health disease profiles [17]. Biofield Energy Healing Treatment has gained rapid rapport as a holistic alternative and complementary medicine therapy that has a significant impact on living organisms and nonliving materials without any adverse effects and in a manner that is more cost-effective than more conventional methods. Biofield Energy Treatment (The Trivedi Effect ${ }^{\circledR}$ ) results has been published in numerous peer-reviewed science journals with significant outcomes in many scientific fields such as cancer research [18], microbiology [19-21], genetics [22, 23], pharmaceutics [24, 25], nutraceuticals [26], organic compounds [27, 28], agricultural science [29, 30], and changing the structure of the atom in relation to various metals, ceramics, polymers and chemicals in materials science [31-33].

In this study, the authors sought to explore the impact of the Biofield Energy Treatment (The Trivedi Effect ${ }^{\circledR}$ ) on the given herbomineral formulation and Biofield Energy Treatment per se to the animals, which might improve the immunomodulatory function in cyclophosphamide induced immunosuppression in male Sprague Dawley rat model by identification of various immunity biomarkers.

\section{Materials and Methods}

\subsection{Chemicals and Reagents}

The chemicals such as pyrogallol and carboxymethyl cellulose sodium were purchased from Sigma Chemical Co. (St. Louis, MO). Ashwagandha (Withania somnifera) root extract powder ( $\geq 5 \%$ of total withanolides) was procured from Sanat Products Ltd., India. Zinc chloride and 
magnesium (II) gluconate hydrate were procured from TCI, Japan. Sodium selenate was procured from Alfa Aesar, USA. Levamisole hydrochloride was procured from Sigma, USA. All other chemicals used were of analytical grade available in India.

\subsection{Experimental Animals}

A total number of 56 healthy male Sprague Dawley rats, weighing between 220-250 grams, were used for the study ( $\mathrm{n}=8$, in each group). The animals were purchased from $\mathrm{M} / \mathrm{s}$. Vivo Bio Tech Ltd., Hyderabad, India. Standard rodent diet was procured from M/s. Golden feeds, Mehrauli, New Delhi, India and provided ad libitum to all the groups of animals during the experiment under controlled conditions with a temperature of $22 \pm 3{ }^{\circ} \mathrm{C}$, humidity of $30 \%$ to $70 \%$ and a 12 hour light/12-hour dark cycle. The animals were acclimatized for 5 days prior to the experiment, and all were accessed once daily for clinical signs, behaviors, morbidity and mortality. All the procedures were in strict accordance with the Guide for the Care and Use of Laboratory Animals published by the US National Institutes of Health. The approval of the Institutional Animal Ethics Committee that was obtained prior to carrying out the animal experiment.

\subsection{Energy of Consciousness Treatment Strategies}

The test formulation was divided into two parts. One part of the test formulation was treated with the Biofield Energy by renowned Biofield Energy Healers (also known as The Trivedi Effect ${ }^{\circledR}$ ) and coded as the Biofield Energy Treated formulation, while the second part of the test formulation did not receive any sort of treatment and was defined as the untreated test formulation. This Biofield Energy Treatment was provided through a group of seven Biofield Energy Healers who participated in this study and performed the Biofield Energy Treatment remotely. Six Biofield Energy Healers were remotely located in the U.S.A. and one was located in Canada, while the test herbomineral formulation was located in the research laboratory of Dabur Research Foundation, New Delhi, India. Additionally, one group of animals also received the Biofield Energy Treatment per se by the Biofield Energy Healers under similar conditions. This Biofield Energy Treatment was administered for 5 minutes through the Healer's unique Energy Transmission process remotely to the test formulation under laboratory conditions. None of the Biofield Energy Healers in this study visited the laboratory in person, nor had any contact with the herbomineral samples. Further, the control group was treated with a "sham" healer for comparative purpose. The sham healer did not have any knowledge about the Biofield Energy Treatment. After that, the Biofield Energy treated and untreated samples were kept in similar sealed conditions and used for identification of immunological biomarkers.

\subsection{Antigen (Sheep RBC)}

The fresh sheep blood was collected aseptically from the jugular vein of a healthy sheep and transferred immediately to the heparinized tube. The collected erythrocytes were separated from plasma by centrifugation $\left(400 \mathrm{~g}, 10^{\circ} \mathrm{C}, 10\right.$ minutes), washed twice with the normal saline and then further diluted in saline, which were analyzed using a Hematology analyzer (Abbott Model-CD-3700). Based on the number of erythrocytes, the samples were further diluted (using saline) before injecting to the rats [34].

\subsection{Experimental Procedure}

After seven days of acclimatization, the animals were grouped based on the body weight. A total of seven groups (G) were included i.e. G1 to G7 with eight animals $(n=8)$ in each group. The animals were received cyclophosphamide in all the groups except G1 at a dose of $10 \mathrm{mg} / \mathrm{kg}$ in normal saline through intraperitoneal (i.p.) route 1 hour before administration of the test formulation, from day 1 to 13 . However, G1, G2, and G6 group's animals were administered with vehicle $(0.5 \%$ carboxy methyl cellulosesodium salt) via oral gavage. G3 group animals received reference item, levamisole at a dose of $75 \mathrm{mg} / \mathrm{kg}$ body weight. G4 group animals received Biofield Energy Treated test formulation at $1105.005 \mathrm{mg} / \mathrm{kg} \mathrm{b} . \mathrm{wt}$, (per oral) p.o. and G5 animals received the untreated test formulation at the same dose by oral route. Further, G6 group animals received Biofield Energy Treatment per se at day -15, without test formulation, while G7 group animals received Biofield Energy Treated test formulation at day -15 . The freshly prepared suspensions of the Biofield Energy Treated and untreated test formulations were administered orally to the G4 and G5 groups, respectively at a dose of 1105.005 $\mathrm{mg} / \mathrm{kg}$ from day 1 to day 25. However, Biofield Energy Treated test formulation was administered orally to the G7 group at same dose from day -15 to day 25 . The treatment was continued to all the tested groups (G1 to G7) with 5 $\mathrm{mL} / \mathrm{kg}$ body weight dose volume.

However, all the animals (G1-G7) were challenged with sheep red blood cells (sRBC) $\left(0.5 \times 10^{9} / 100\right.$ gm; i.p. $)$ on day 7 and 13, as the antigenic material to sensitize them for immunological studies. On day $13^{\text {th }}$ and $20^{\text {th }}$ the animals were bled and the samples were subjected to hemagglutination test for cellular $\left(\mathrm{CD} 4^{+}\right.$and $\left.\mathrm{CD}^{+}\right)$and humoral (IgG and $\operatorname{IgM})$ immune responses. On same day $20^{\text {th }}$, the animals were challenged with $\operatorname{sRBC}\left(0.5 \times 10^{9}\right.$ cells $/ 50 \mu \mathrm{L} /$ rat $)$ in sub-planter region and on day $21^{\text {st }}(24$ hours) paw volume was measured to evaluate the cellular immune response. The body weight and food consumption were measured daily before treatment. The animals were kept on overnight fasting on day 24 , followed by blood collection from retro-orbital plexus under isoflurane anaesthesia and the samples were subjected for haematology analysis, serum for biochemistry and hormone estimation. A portion of liver samples were snap frozen and stored in $-80^{\circ} \mathrm{C}$ for the estimation of anti-oxidant parameters (SOD, Catalase, and LPO). At the end of the study, animals were euthanized by $\mathrm{CO}_{2}$ asphyxiation as per in-house approved standard protocol. Different organs of all 
animals were excised, weighed and preserved for histopathological analysis.

\subsection{Assessment of Cellular and Humoral Responses}

Humoral immune response, IgG and IgM were estimated using Mini Vidas, Biomeurix (French) from serum, using commercially available kits. The flow cytometry was used to evaluate the $\mathrm{CD}^{+}$and $\mathrm{CD}^{+}$cells in blood as a measure of the cellular immune response. The mean value was calculated for each group with SEM. The percent change in the Biofield Energy Treated group was calculated compared to the vehicle treatment group.

\subsection{Assessment of Hematology Parameters}

Hematological parameters such as total leukocyte count (TLC), and differential leukocyte counts (DLC), were analyzed using a Hematology analyzer (Abbott Model-CD3700) in blood samples.

\subsection{Assessment of Lipid Profile and Hepatic Enzymes}

Glucose, total cholesterol (TC), triglycerides (TG), low density lipoprotein (LDL), high density lipoprotein (HDL), very low density lipoprotein (VLDL), alkaline phosphatase (ALP), serum glutamic oxaloacetic transaminase (SGOT), and serum glutamate-pyruvate transaminase (SGPT) were analyzed using serum $[35,36]$.

\subsection{Assessment of Sex Hormone - Testosterone}

The level of testosterone was analyzed in serum using commercial kits. The mean value was calculated for each group with SEM. The percent change in the treated group was calculated compared to the vehicle treatment group.

\subsection{Assessment of Antioxidant Profile by ELISA Assay}

Superoxide dismutase (SOD), catalase and lipid peroxidase (LPO) were analyzed by ELISA assay using liver homogenate sample [37-39].

\subsection{Statistical Analysis}

All the results were expressed as mean \pm standard error of mean (SEM) and subjected to statistical analysis using Sigma Plot (Version 11.0). Student's $t$-test was performed for comparison of the individual treatment group with control. The $p \leq 0.05$ was considered as statistically significant.

\section{Results and Discussion}

\subsection{Measurement of Humoral Immune Response}

The effects of the Biofield Energy Treated and untreated test formulations on immunoglobulin levels (IgG and IgM) are demonstrated in the Figure 1. IgG and IgM are the major immunoglobulin that are considered as important role in complement activation, opsonization, neutralization of toxins, etc. There was a slight increased level of $\mathrm{IgG}$ in the Biofield Energy Treated test formulation group (G4) when compared to the disease control group (G2). The level of IgM in all the tested groups were decreased as compared to the disease control group. The level of IgM in the Biofield Energy Treated test formulation, and Biofield Energy Treatment per se (G6) group showed slight decreased by $4.76 \%$ and $9.52 \%$, respectively compared with the disease control. However, the IgG level was significantly increased by $2.89 \%, 6.20 \%$, and $6.20 \%$ in the Biofield Energy Treated test formulation, Biofield Energy Treatment per se (day -15), and Biofield Energy Treated test formulation (day -15), respectively compared with the disease control.
A

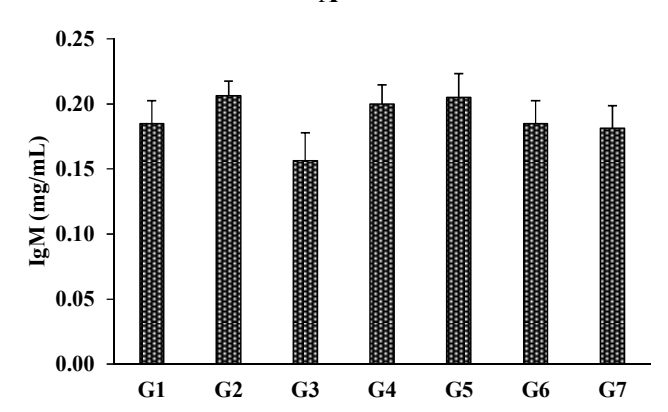

B

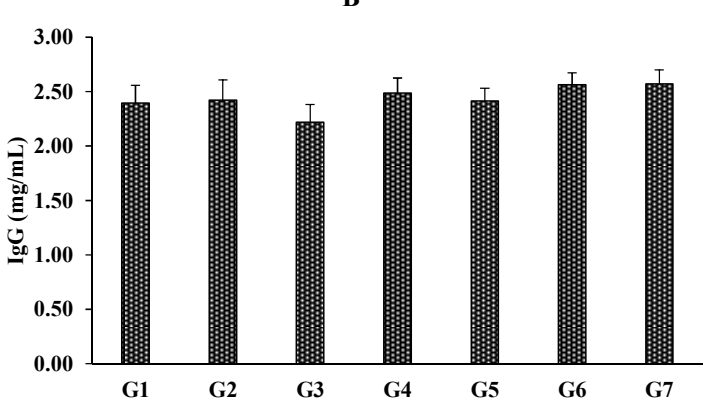

Figure 1. The effect of the test formulation on immunoglobulins, A. IgM and B. IgG after treatment on various groups (G1 - G7) in male SD rats. G1: Normal control; G2: Disease control; G3: Levamisole; G4: Biofield Energy Treated test formulation; G5: Untreated test formulation; G6: Biofield Energy Treatment per se at day -15 (without test formulation); and G7: Biofield Energy Treated test formulation at day -15 . All the values are represented as mean \pm SEM ( $n=8)$.

Overall, the levels of $\operatorname{IgM}$ and $\mathrm{IgG}$ in the Biofield Energy Treated test formulation group were altered, however the IgG response was significantly elevated and showed better response compared with the IgM. However, Biofield Energy Treated test formulation showed improved level of IgG compared with the untreated test formulation. The literature suggest that the components of test formulation, i.e. ashwagandha root extract and the minerals like zinc, selenium, and magnesium have reported with an improved immunoglobulin production $[40,41]$. Thus, the study results showed that the IgG level was significantly increased with the Biofield Energy Treated test formulation (G4) and Biofield Energy Treatment per se (G6) with significant effect compared with the disease control group. 


\subsection{Measurement of Cellular Responses}

The effects of the Biofield Energy Treated and untreated test formulations on ratio of $\mathrm{CD} 4^{+} / \mathrm{CD}^{+}$in male SD rats are demonstrated in Figure 2. The $\mathrm{CD}$ markers i.e. the concentrations of $\mathrm{CD}^{+}$and $\mathrm{CD}^{+}$were analyzed using whole blood. The ratio of $\mathrm{CD}^{+} / \mathrm{CD}^{+}$in normal control (G1), disease control (G2), levamisole (G3), Biofield Energy
Treated test formulation (G4), untreated test formulation (G5), Biofield Treatment per se (day -15) (G6), and Biofield Energy Treated test formulation (day -15) (G7) were 1.56, $1.05,1.16,1.09,1.15,1.18$, and 1.22 , respectively. Overall, the experimental results suggests that the $\mathrm{CD} 4^{+} / \mathrm{CD} 8^{+}$ratio was increased by $3.80 \%, 12.38 \%$, and $16.19 \%$ in the G4, G6, and $\mathrm{G} 7$, respectively compared with the disease control (G2).

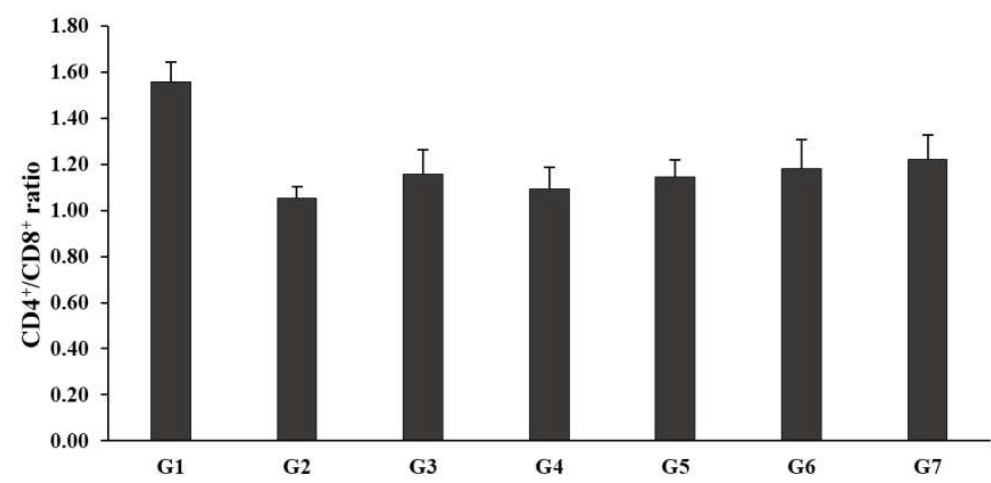

Figure 2. The effect of the test formulation on the ratio of cellular biomarkers (CD4 ${ }^{+} / C D 8^{+}$ration) after treatment on various groups (G1 - G7) in male SD rats. G1: Normal control; G2: Disease control; G3: Levamisole; G4: Biofield Energy Treated test formulation; G5: Untreated test formulation; G6: Biofield Energy Treatment per se at day -15 (without test formulation); and G7: Biofield Energy Treated test formulation at day -15. All the values are represented as mean $\pm \operatorname{SEM}(n=8)$

Lymphocyte populations are categorized as T, B, and natural killer cells, while its subpopulations is categorized as $\mathrm{CD}^{+}$and $\mathrm{CD}^{+}$. Lymphocytes, a category of white blood cell in the immune system, which reflects the immune strength. It is regarded that $\mathrm{CD} 4^{+}$cells can protect and fight against infections, while $\mathrm{CD} 8^{+}$cells have the capacity to kill cancer cells and other invaders. The ratio of $\mathrm{CD}^{+} / \mathrm{CD}^{+}$ reflects the health of immune system and the normal ratio is suggested as 2 . If the ratio is higher, it suggests that the immune system is stronger as compared with the low ratio of $\mathrm{CD}^{+} / \mathrm{CD}^{+}$, which reflects infection [42, 43]. The experimental results suggests that the Biofield Energy Treated test formulation improved the $\mathrm{CD}^{+} / \mathrm{CD}^{+}$ratio by $3.80 \%$, but Biofield Energy Treatment per se group was increased by $12.38 \%$. This suggests that The Trivedi Effect ${ }^{\circledR}$ per se and Biofield Energy Treated test formulation (day -15) groups have the significant capacity to do change in the immune system, and modulate the overall immune function, which can be used against inflammatory disorders, autoimmune diseases, antiaging, and for stress management and prevention.

\subsection{Assessment of Hematology Parameters}

The hematology parameters such as total and differential leucocytes counts of different groups (G1 to G7) are summarized in the Table 1 . The results suggest the animal hematology profile after administration of the Biofield Energy Treated and untreated test formulations were significantly improved compared with the disease control group. Hematology parameters such as TLC, neutrophils, lymphocytes, eosinophils, and monocytes showed an altered profile such as decreased lymphocyte and monocytes count by $0.76 \%$ and $2.10 \%$, respectively in the Biofield Energy Treated test formulation group (G4) compared with the disease control group (G2). TLC and neutrophil levels were increased by $9.64 \%$ and $1.48 \%$, respectively in the G4 group compared with the G2. Besides, Biofield Energy Treatment per se (without test formulation) group (G6) showed an increase in TLC, lymphocytes, and monocytes count by $19.79 \%, 2.87 \%$, and $15.54 \%$, compared with the disease control. Similarly, an improved patterns was also observed in case of Biofield Energy Treated test formulation (day -15) group (G7), such as increased TLC, lymphocytes, eosinophils, and monocytes counts by $51.26 \%, 3.50 \%$, $7.43 \%$, and $36.55 \%$, respectively with respect to the disease control group. However, a slight increase in the count was also reported in case of neutrophils and eosinophils by $1.48 \%$ and $4.57 \%$, respectively in G4 compared with the disease control.

The data suggest the Biofield Energy Treated test formulation (G4) and Biofield Energy Treatment per se (G6) improved the concentration of eosinophils, as they play a major and beneficial role as a modulatory element. A report showed that an increased number of eosinophils was directly related with the multifunctional aspect such as diverse inflammatory and physiologic immune responses [44]. Thus, an improved number of eosinophil after treatment might regulate the immune system and can be useful against many autoimmune disorders.

However, various reports suggested an improved hematological parameters after administration of different herbal extracts like ashwagandha [45], Afzelia africana [46], etc. Besides, the important minerals were widely reported to improve the hematological profile that could improve the immunity, such as zinc [47], selenium [48], and magnesium 
[49], which were reported with a significant improved biochemical profile. The test herbomineral formulations, is the combination of the herbal extract and minerals, which might be responsible for improving the hematological profile of male SD rats, as matched with the existing literature. However, the Biofield Energy Treatment further an improved the action of test formulation and showed significant changes with respect to the untreated test formulation. Thus, it can be assumed that Biofield Energy Treatment per se (The Trivedi Effect $^{\circledR}$ ) has the capacity to improve the immunomodulatory potential of test formulation by improving the hematological profile.

Table 1. Hematology profile of male Sprague Dawley rats after administration of test formulation.

\begin{tabular}{|c|c|c|c|c|c|}
\hline Group (G) & TLC (thousand $/ \mathrm{mm}^{3}$ ) & Neutrophils (\%) & Lymphocytes (\%) & Eosinophils (\%) & Monocyte (\%) \\
\hline 1 & $10.18 \pm 0.74$ & $18.38 \pm 2.00$ & $78.25 \pm 2.15$ & $1.50 \pm 0.19$ & $1.88 \pm 0.23$ \\
\hline 2 & $5.91 \pm 0.31$ & $30.38 \pm 2.36$ & $65.50 \pm 2.51$ & $1.75 \pm 0.25$ & $2.38 \pm 0.26$ \\
\hline 3 & $8.74 \pm 0.40$ & $35.25 \pm 2.28$ & $59.00 \pm 2.61$ & $1.63 \pm 0.18$ & $4.13 \pm 0.81$ \\
\hline 4 & $6.48 \pm 0.51$ & $30.83 \pm 2.33$ & $65.00 \pm 2.37$ & $1.83 \pm 0.31$ & $2.33 \pm 0.21$ \\
\hline 5 & $7.14 \pm 0.69$ & $31.25 \pm 2.23$ & $64.75 \pm 2.40$ & $1.50 \pm 0.19$ & $2.50 \pm 0.19$ \\
\hline 6 & $7.08 \pm 0.62$ & $28.38 \pm 1.28$ & $67.38 \pm 1.43$ & $1.50 \pm 0.19$ & $2.75 \pm 0.16$ \\
\hline
\end{tabular}

G: Group; G1: Normal control; G2: Disease control; G3: Levamisole; G4: Biofield Energy Treated test formulation; G5: Untreated test formulation; G6: Biofield Energy Treatment per se at day -15 (without test formulation); and G7: Biofield Energy Treated test formulation at day -15. All the values are represented as mean $\pm \operatorname{SEM}(\mathrm{n}=8)$. TLC: Total leukocyte count; \%: Percentage, ${ }^{* * *} p \leq 0.001$ (compared to the disease control).

\subsection{Measurement of Glucose and Lipid Biomarkers}

The results of biochemical parameters such as glucose, total cholesterol (TC), triglycerides (TG), high density lipoprotein (HDL), low density lipoprotein (LDL), and very low density lipoprotein (VLDL) of different groups (G1 to G7) are summarized in the Table 2. The results showed the concentration of glucose was increased by $11.78 \%, 18.60 \%$, and $56.84 \%$ in the G4, G6, and G7 group, respectively compared with the disease control group. The level of triglycerides was significantly decreased in the Biofield Energy Treated test formulation (G4) and Biofield Energy Treated test formulation, day -15 (G7), by $10.54 \%$ and $4.20 \%$, respectively compared with the disease control. However, Biofield Energy Treatment per se (G6) increased the TC concentration by $11.59 \%$ compared with the disease control. The level of triglycerides was increased in all the group with respect to disease control, like increased percentage by $24.44 \%, 35.80 \%$, and $22.27 \%$ in G4, G6, and G7 group, respectively compared with the G2. However, the level of HDL was improved in the Biofield Energy Treatment per se (day -15) group (G6) and G7 by $11.69 \%$ and $1.06 \%$, respectively as compared with the G2. Similarly, the LDL level was significantly decreased by $10.52 \%$ in the Biofield Energy Treated test formulation (G4) compared with the G2. Although, VLDL level was increased in all the groups, i.e. by $24.31 \%, 35.80 \%$, and $22.34 \%$ in the G4, G6, and G7 groups, respectively compared with the $\mathrm{G} 2$.

Overall, the Biofield Energy Treated test formulation and Biofield Energy Treatment per se were observed with the beneficial effect on animal lipid profile. Scientific literature reported that herbal extract such as ashwagandha along with minerals like selenium, zinc, and magnesium have a significant effect on lipid profile, serum cholesterol, LDL, HDL, etc. with no clinical adverse effects [50-54]. Thus, it can be assumed that the altered lipid profile was due to the constituents present in the herbomineral formulation, but Biofield Energy Treated test formulation and Biofield Energy Treatment per se showed a significant improved lipid profile as compared with the untreated test formulation. It suggest that the Biofield Energy Treatment significantly improved the immunomodulatory activity by altering the lipid profile, which would be helpful against many autoimmune and antiinflammatory disorders.

Table 2. Lipid profile analysis after treatment with the test formulation on male rats.

\begin{tabular}{|c|c|c|c|c|c|c|}
\hline Group (G) & Glucose (mg/dL) & TC (mg/dL) & Triglyceride $\mathrm{mg} / \mathrm{dL}$ ) & HDL (mg/dL) & LDL (mg/dL) & VLDL (mg/dL) \\
\hline 1 & $131.15 \pm 8.78$ & $84.18 \pm 3.52$ & $73.11 \pm 7.99$ & $25.25 \pm 1.06$ & $44.79 \pm 2.26$ & $14.62 \pm 1.60$ \\
\hline 2 & $110.90 \pm 5.70$ & $92.85 \pm 7.57$ & $63.54 \pm 9.78$ & $27.81 \pm 2.27$ & $52.28 \pm 3.95$ & $12.71 \pm 1.96$ \\
\hline 3 & $122.49 \pm 8.31$ & $111.25 \pm 13.25$ & $99.56 \pm 9.18$ & $33.35 \pm 3.97$ & $59.66 \pm 7.74$ & $19.91 \pm 1.84$ \\
\hline 4 & $123.96 \pm 10.98$ & $89.40 \pm 6.42$ & $79.07 \pm 9.06$ & $26.82 \pm 1.92$ & $46.78 \pm 4.76$ & $15.80 \pm 1.81$ \\
\hline 5 & $131.09 \pm 7.18$ & $83.06 \pm 3.49$ & $74.06 \pm 6.52$ & $24.89 \pm 1.05$ & $43.30 \pm 1.64$ & $14.81 \pm 1.30$ \\
\hline 6 & $131.53 \pm 8.62$ & $103.58 \pm 3.57$ & $86.29 \pm 4.55$ & $31.06 \pm 1.07$ & $55.24 \pm 2.68$ & $17.26 \pm 0.91$ \\
\hline 7 & $173.94 \pm 15.20^{* *}$ & $88.95 \pm 5.71$ & $77.69 \pm 10.14$ & $28.09 \pm 2.44$ & $54.03 \pm 3.86$ & $15.55 \pm 2.02$ \\
\hline
\end{tabular}

G: Group; G1: Normal control; G2: Disease control; G3: Levamisole; G4: Biofield Energy Treated test formulation; G5: Untreated test formulation; G6: Biofield Energy Treatment per se at day -15 (without test formulation); and G7: Biofield Energy Treated test formulation at day -15. All the values are represented as mean \pm SEM $(n=8)$. TC: Total Cholesterol; HDL: High density lipoprotein; LDL: Low density lipoprotein; VLDL: Very low density lipoprotein; mg/dL: Milligram per deciliter; ${ }^{*} p \leq 0.01$ (compared to the disease control). 


\subsection{Measurement of Hepatic and Cardiac Biomarkers}

The biochemical parameters i.e. hepatic enzymes like serum glutamate oxaloacetate transaminase (SGOT), serum glutamate pyruvate transaminase (SGOT), alkaline phosphatase (ALP) and cardiac enzyme creatine kinase myocardium band (CK-MB), and others biomarkers such as, total bilirubin, albumin, and globulin in different groups (G1 to G7) were evaluated and are shown in the Table 3. The level of SGOT, CK-MB, TP, A, and G were significantly decreased by $4.04 \%, 23.54 \%, 1.68 \%, 1.54 \%$, and $1.80 \%$, respectively in the Biofield Energy Treated test formulation
(G4) compared with the disease control (G2). However, the Biofield Energy Treatment per se group (G6) also showed a decreased level of SGOT, CK-MB, and $\mathrm{A} / \mathrm{G}$ ratio by $2.08 \%$, $16.23 \%$, and $3.40 \%$, respectively compared with the disease control (G2). However, SGOT level was significantly $\left({ }^{* *} p \leq 0.01\right)$ decreased by $18.88 \%$ in the $\mathrm{G} 7$ group compared with the G2 group. The other tested parameters were slightly increased in all the treated group compared to the disease control group such as total bilirubin, total protein, albumin, and globulin. However, the change was not significant in all the treated groups compared to the disease control (G2).

Table 3. Evaluation of hepatic biomarkers after treatment with the test formulation on male rats.

\begin{tabular}{|c|c|c|c|c|c|c|c|c|c|}
\hline $\begin{array}{l}\text { Group } \\
\text { (G) }\end{array}$ & TB (mg/dL) & SGOT (U/L) & SGPT (U/L) & $\operatorname{ALP}(\mathbf{U} / \mathbf{L})$ & CK-MB (U/L) & TP $(g / d L)$ & $A(g / d L)$ & $\mathbf{G}(\mathrm{g} / \mathrm{dL})$ & A/G ratio \\
\hline 1 & $0.14 \pm 0.01$ & $230.21 \pm 7.55$ & $43.69 \pm 1.82$ & $201.14 \pm 15.47$ & $1198.80 \pm 66.80$ & $8.40 \pm 0.11$ & $3.91 \pm 0.03$ & $4.49 \pm 0.08$ & $0.87 \pm 0.01$ \\
\hline 3 & $0.17 \pm 0.02$ & $201.49 \pm 9.01$ & $49.44 \pm 4.77$ & $216.84 \pm 13.36$ & $803.56 \pm 70.55$ & $8.36 \pm 0.18$ & $3.89 \pm 0.06$ & $4.47 \pm 0.13$ & $0.87 \pm 0.01$ \\
\hline 4 & $0.14 \pm 0.02$ & $193.77 \pm 17.37$ & $44.37 \pm 7.28$ & $180.93 \pm 7.34$ & $788.12 \pm 91.52$ & $8.18 \pm 0.16$ & $3.82 \pm 0.04$ & $4.36 \pm 0.17$ & $0.88 \pm 0.04$ \\
\hline 6 & $0.12 \pm 0.01$ & $197.73 \pm 13.71$ & $47.54 \pm 2.91$ & $291.18 \pm 11.38$ & $863.41 \pm 83.00$ & $8.59 \pm 0.10$ & $3.93 \pm 0.04$ & $4.65 \pm 0.08$ & $0.85 \pm 0.01$ \\
\hline 7 & $0.13 \pm 0.02$ & $163.81 \pm 11.71^{*}$ & $40.61 \pm 2.52$ & $264.43 \pm 10.77$ & $624.38 \pm 84.02^{* *}$ & $8.54 \pm 0.14$ & $3.91 \pm 0.06$ & $4.63 \pm 0.11$ & $0.85 \pm 0.02$ \\
\hline
\end{tabular}

G: Group; G1: Normal control; G2: Disease control; G3: Levamisole; G4: Biofield Energy Treated test formulation; G5: Untreated test formulation; G6: Biofield Energy Treatment per se at day -15 (without test formulation); and G7: Biofield Energy Treated test formulation at day -15 . All the values are represented as mean \pm SEM $(n=8)$. SGOT: Serum glutamic oxaloacetic transaminase; SGPT: Serum glutamate-pyruvate transaminase; ALP: Alkaline phosphatase; CK-MB: Creatine kinase-myocardial band; TB: Total bilirubin; TP: Total protein; A: Albumin; G: Globulin; A/G: Albumin/Globulin ratio; U/L: Unit per liter; mg/dL: Milligram per deciliter, ${ }^{*} p \leq 0.05$ and $* * \leq \leq 0.01$ denoted as statistically significant compared to the disease control.

The level of hepatic biomarkers in the disease control group (G2) was significantly increased, which suggest liver toxicity according to the data of TB, SGOT, SGPT, ALP, TP, CK-MB, albumin, and globulin as compared with the normal control (G1). Further, the data showed Biofield Energy Treated test formulation and Biofield Energy Treatment per se groups protect the hepatic liver enzymes, with a significant decreased amount of SGOT, ALP, CK-MB, TP, A, G, and $\mathrm{A} / \mathrm{G}$ ratio. These enzymes are the biomarkers for liver toxicity and suggests liver damage [55]. The herbomineral formulation and its individual components are reported to have beneficial effect to protection the hepatic biomarkers. Ashwagandha was reported to have significant effect on hepatic enzymes, while minerals such as selenium, zinc, and magnesium have been reported with a significant effect on liver biomarkers [56-59]. Thus, it can be concluded that Biofield Energy Treatment per se and Biofield Energy Treated test formulation could protect the liver toxicity and could help in regulating the immune function by altering the level of hepatic biomarkers.

\subsection{Measurement of Sex Hormone}

The effects of the Biofield Energy Treated and untreated test formulations on the level of sex hormone, testosterone in male SD rats are shown in the Figure 3. Serum testosterone level was significantly altered in all the tested groups. The level of testosterone (in $\mathrm{ng} / \mathrm{dL}$ ) in disease control (G2), levamisole (G3), Biofield Energy Treated test formulation (G4), untreated test formulation (G5), Biofield Energy Treatment per se (G6) and Biofield Energy Treated test formulation, day -15 (G7) were $137.0 \pm 36.37,235.75 \pm$ $105.72,32.00 \pm 9.11,177.43 \pm 72.40,111.75 \pm 52.18$, and $76.63 \pm 28.45 \mathrm{ng} / \mathrm{dL}$, respectively. Overall, the level of testosterone was decreased by $76.67 \%, 18.43 \%$, and $44.06 \%$ in the G4, G6, and G7 groups, respectively compared with the disease control group.

The literature data suggests that all the individual constituents of test formulation have a significant effect on testosterone level. Individually, ashwagandha and the minerals were reported to have a significant effect in altering the testosterone level [60-62]. The literature also suggests the ameliorative potential of sodium selenite and zinc sulfate on intensive-swimming-induced testicular disorders, which reported significantly role of selenium and zinc in decreasing the plasma level of testosterone in mature male rats [63]. The study results showed a significant effect of the Biofield Energy Treated test formulation supplementation on testosterone level, thus it can be assumed that Biofield Energy Treatment has the significant capacity to alter the sex hormones. 


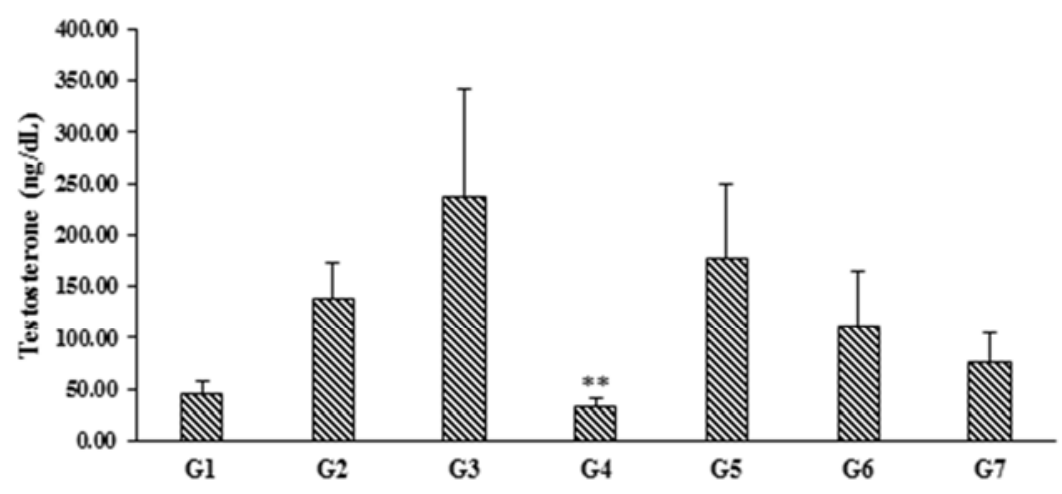

Figure 3. The effect of the test formulation on the level of testosterone. G: Group; G1: Normal control; G2: Disease control; G3: Levamisole; G4: Biofield Energy Treated test formulation; G5: Untreated test formulation; G6: Biofield Energy Treatment per se at day -15 (without test formulation); and G7: Biofield Energy Treated test formulation at day -15 . All the values are represented as mean $\pm S E M(n=8) .{ }^{* *} p \leq 0.01$ compared to the disease control.

\subsection{Measurement of Antioxidant Profile by ELISA}

The effects of the Biofield Energy Treated and untreated test formulations on levels of various antioxidant enzymes such as SOD, LPO, and CAT in male SD rats are demonstrated in Figure 4. The antioxidant biomarkers such as SOD, LPO, and CAT were evaluated in liver samples. The LPO level in G4 and G6 was increased by $18.88 \%$ and $3.33 \%$, respectively compared with the G2, while in other groups the LPO level was decreased by $59.63 \%$ in G7 group. However, the SOD level in G4, G6, and G7 was significantly decreased by $57.23 \%, 59.03 \%$, and $49.60 \%$, respectively compared with the G2 group. Similarly, decreased pattern of catalase (CAT) activity was reported by $42.26 \%, 48.35 \%$, and $57.64 \%$ in G4, G6, and G7, respectively compared with the G2 group. Overall, the LPO level was significantly decreased by $59.63 \%$ in the Biofield Energy Treated test formulation (day -15), while the level of antioxidants were significantly decreased. Scientific reports suggest that decreased level of free radicles can be beneficial against many inflammatory diseases [64]. This suggests that Biofield Energy Treatment has the significant capacity to minimize the level of free radicles, which can be helpful to modulate the immune system against several inflammatory and autoimmune diseases.
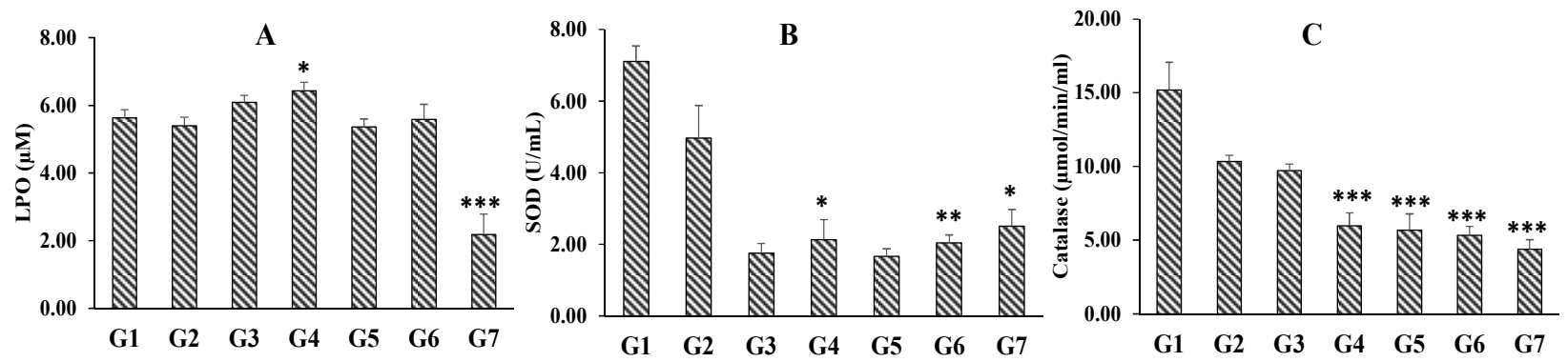

Figure 4. The effect of the test formulation on anti-oxidative markers (A). LPO, (B). SOD, and (C). Catalase after treatment in male SD rats. All the values are represented as mean $\pm \operatorname{SEM}(n=8) ;{ }^{*} p \leq 0.05,{ }^{* *} p \leq 0.01$ and ${ }^{* * *} p \leq 0.001$ (compared to the disease control).

\section{Conclusions}

Based on the current findings and the results of the immune biomarkers assay after oral administration of herbomineral formulation exhibited significantly impact of The Trivedi Effect ${ }^{\mathbb{R}}$ - Energy of Consciousness Healing Treatment (Biofield Energy Healing Treatment) on animals and test formulation group, which showed a significant improved humoral and cellular immunity. In case of humoral immune response, the IgG level was significantly increased by $2.89 \%, 6.20 \%$, and $6.20 \%$ in the Biofield Energy Treated test formulation (G4), Biofield Energy Treatment per se at day -15 (G6), and Biofield Energy Treated test formulation at day -15 (G7), respectively as compared with the disease control $(\mathrm{G} 2)$. The ratio of $\mathrm{CD}^{+} / \mathrm{CD}^{+}$as cellular immune response was increased in the G4, G6, and G7 groups by $3.80 \%, 12.38 \%$, and $16.19 \%$, respectively compared with the G2 group. This increase in $\mathrm{CD} 4^{+} / \mathrm{CD}^{+}$ratio suggest strong immune strength after Biofield Energy Healing. Besides, a significant improved hematological profile such as TLC and neutrophil was increased by $9.64 \%$ and $1.48 \%$, respectively in the G4 group compared with disease control group (G2). However, Biofield Energy Treatment group per se (G7) also showed a significant increased levels of TLC, lymphocytes, and monocytes by $19.79 \%, 2.87 \%$, and $15.54 \%$, respectively compared with the disease control (G2). Similarly, the Biofield Energy Treated test formulation (day -15) (G7) group showed an improved level of TLC, lymphocytes, eosinophils, and monocytes by $51.26 \%, 3.50 \%, 7.43 \%$, and $36.55 \%$, respectively compared with disease control group 
(G2). In biochemical estimation, the level of total cholesterol was significantly decreased in the Biofield Energy Treated test formulation and Biofield Energy Treated test formulation at day -15 by $10.54 \%$ and $4.20 \%$, respectively compared with the disease control. Similarly, HDL level was increased by $11.69 \%$ in the Biofield Energy Treatment per se (day -15) group compared with the disease control group (G2). LDL level was significantly decreased by $10.52 \%$ in the Biofield Energy Treated test formulation (G4) compared with the disease control group (G2). Among hepatic biomarkers, SGOT, TP, A, and G levels were significantly decreased, while CK-MB level was decreased by $23.54 \%$ in the Biofield Energy Treated test formulation (G4) as compared with the disease control (G2). Besides, Biofield Energy Treatment per se group (G6) showed decrease in the values of SGOT, CK$\mathrm{MB}$, and $\mathrm{A} / \mathrm{G}$ by $2.08 \%, 16.23 \%$, and $3.40 \%$, respectively compared with the disease control. The level of testosterone was significantly altered in the Biofield Energy Treated test formulation compared with the disease control group. Antioxidant assay suggests that the free radical, LPO was significantly decreased by $59.63 \%$ in the Biofield Energy Treated test formulation at day -15 (G7) compared with the disease control, while antioxidants such as SOD and catalases were significantly altered after Biofield Energy Treatment to the test formulation compared with the disease control group.

Overall, it can be concluded that the novel herbomineral formulation after treatment with the Trivedi Effect ${ }^{\circledR}$-Biofield Energy Healing remotely by the seven Biofield Energy Healers enhanced the herbomineral test formulation's antiinflammatory and immunomodulatory properties. Therefore, the Biofield Energy Treated test formulation may act as an effective anti-inflammatory and immunomodulatory product, and it can be used as a Complementary and Alternative Medicine (CAM) with a safe therapeutic index for various autoimmune disorders such as Lupus, Systemic Lupus Erythematosus, Fibromyalgia, Addison Disease, Hashimoto Thyroiditis, Celiac Disease (gluten-sensitive enteropathy), Multiple Sclerosis, Dermatomyositis, Graves' Disease, Myasthenia Gravis, Pernicious Anemia, Aplastic Anemia, Scleroderma, Psoriasis, Rheumatoid Arthritis, Reactive Arthritis, Type 1 Diabetes, Sjogren Syndrome, Crohn's Disease, Vasculitis, Vitiligo, Chronic Fatigue Syndrome and Alopecia Areata, as well as inflammatory disorders such as Irritable Bowel Syndrome (IBS), Asthma, Ulcerative Colitis, Alzheimer's Disease, Parkinson's Disease, Atherosclerosis, Dermatitis, Hepatitis, and Diverticulitis. Further, the Biofield Energy Healing Treated test formulation can also be used in the prevention of immune-mediated tissue damage in cases of organ transplants (for example heart transplants, kidney transplants and liver transplants), for anti-aging, stress prevention and management, and in the improvement of overall health and quality of life.

\section{Abbreviations}

Na-CMC: Sodium carboxymethyl cellulose; SD: Sprague
Dawley; TC: Total cholesterol; TG: Triglycerides; LDL: Low density lipoprotein; HDL: High density lipoprotein; VLDL: Very low density lipoprotein; ALP: Alkaline phosphatase; SGOT: Serum glutamic oxaloacetic transaminase; SGPT: Serum glutamate-pyruvate transaminase; TLC: Total leukocyte count; DLC: Differential leukocyte count; CKMB: Creatine kinase myocardium band; CAT: Catalase; SOD: Superoxide dismutase; LPO: Lipid peroxidation; CD: Cluster differentiation

\section{Acknowledgements}

The authors are gratefully acknowledged to Trivedi science, Trivedi Global, Inc., and Trivedi master wellness and to Dabur Research Foundation (DRF), India for their support.

\section{References}

[1] Janeway CA Jr (2001) How the immune system protects the host from infection. Microbes Infect 3: 1167-1171.

[2] William JE (2001) Review of antiviral and immunomodulatory properties of plants of the Peruvian rainforest. Alter Med Rev 6: 567-579.

[3] Mahima, Rahal A, Deb R, Latheef SK, Abdul Samad H, Tiwari R, Verma AK, Kumar A, Dhama K (2012) Immunomodulatory and therapeutic potentials of herbal, traditional/indigenous and ethnoveterinary medicines. Pak J Biol Sci 15: 754-774.

[4] Sharma ML, Rao CS, Duda PL (1994) Immunostimulatory activity of Picrorhiza kurroa leaf extract. J Ethnopharmacol 41: 185-192.

[5] Wang JZ, Mao XJ, Ito H, Shimura K (1991) Immunomodulatory activity of polysaccharide from Acanthopanex obovatus roots. Planta Med 57: 335-336

[6] Karley D, Gupta D, Tiwari A (2011) Biomarkers: The future of medical science to detect cancer. J Mol Biomark Diagn 2: 118 .

[7] Lukác N, Massanyi P (2007) Effects of trace elements on the immune system. Epidemiol Mikrobiol Imunol 56: 3-9.

[8] Galland L (1998) Magnesium and immune function: An overview. Magnesium 7: 290 - 299.

[9] Wintergerst ES, Maggini S, Hornig DH (2007) Contribution of selected vitamins and trace elements to immune function. Ann Nutr Metab 51: 301 - 323.

[10] Ziauddin M, Phansalkar N, Patki P, Diwanay S, Patwardhan B (1996) Studies on the immunomodulatory effects of ashwagandha. J Ethnopharmacol 50: 69-76.

[11] Singh N, Bhalla M, de Jager P, Gilca M (2011) An overview on ashwagandha: A rasayana (rejuvenator) of Ayurveda. Afr J Tradit Complement Altern Med 8: 208-213.

[12] James SJ, Swenseid M, Makinodan T (1987) Macrophagemediated depression of T-cell proliferation in zinc-deficient mice. J Nutrition 117: 1982. 
[13] Engle TE, Nockels DF, Kimberling CV, Weaber DL, Johnson AB (1997) Zinc repletion with organic and inorganic forms of zinc and protein turnover in marginally zinc-deficient calves. $\mathrm{J}$ Anim Sci 75: 3074

[14] Salimian J, Arefpour MA, Riazipour M, Poursasan N (2004) Immunomodulatory effects of selenium and vitamin $\mathrm{E}$ on alterations in $\mathrm{T}$ lymphocyte subsets induced by $\mathrm{T}-2$ toxin. Immunopharmacol Immunotoxicol 36: 275-281.

[15] Sugimoto J, Romani AM, Valentin-Torres AM, Luciano AA, Ramirez Kitchen CM, Funderburg N, Mesiano S, Bernstein HB (2012) Magnesium decreases inflammatory cytokine production: A novel innate immunomodulatory mechanism. J Immunol 188: 6338-6346.

[16] Rubik B (1994) Manual healing methods. Alternative medicine: expanding medical horizons, Washington, DC, US Government Printing Office, NIH Publication No. 094066.

[17] Cooper EL (2007) The immune system and complementary and alternative medicine. Evid Based Complement Alternat Med 4: 5-8.

[18] Trivedi MK, Patil S, Shettigar H, Mondal SC, Jana S (2015) In vitro evaluation of biofield treatment on viral load against human immunodeficiency-1 and cytomegalo viruses. American Journal of Health Research 3: 338-343.

[19] Trivedi MK, Patil S, Shettigar H, Mondal SC, Jana S (2015) In vitro Evaluation of biofield treatment on Enterobacter cloacae: Impact on antimicrobial susceptibility and biotype. J Bacteriol Parasitol 6: 241.

[20] Trivedi MK, Patil S, Shettigar H, Mondal SC, Jana S (2015) Evaluation of Biofield Modality on Viral Load of Hepatitis B and C Viruses. J Antivir Antiretrovir 7: 083-088.

[21] Trivedi MK, Patil S, Shettigar H, Mondal SC, Jana S (2015) An impact of biofield treatment: Antimycobacterial susceptibility potential using BACTEC 460/MGIT-TB system. Mycobact Dis 5: 189.

[22] Trivedi MK, Branton A, Trivedi D, Nayak G, Mondal SC, Jana S (2015) Evaluation of antibiogram, genotype and phylogenetic analysis of biofield treated Nocardia otitidis. Biol Syst Open Access 4: 143.

[23] Trivedi MK, Branton A, Trivedi D, Nayak G, Gangwar M, Jana S (2015) Antibiogram, biochemical reactions, and genotypic pattern of biofield treated Pseudomonas aeruginosa. J Trop Dis 4: 181.

[24] Trivedi MK, Patil S, Tallapragada RM (2013) Effect of bio field treatment on the physical and thermal characteristics of vanadium pentoxide powders. J Material Sci Eng S 11: 001.

[25] Trivedi MK, Branton A, Trivedi D, Shettigar H, Bairwa K, Jana S (2015) Fourier transform infrared and ultravioletvisible spectroscopic characterization of biofield treated salicylic acid and sparfloxacin. Nat Prod Chem Res 3: 186.

[26] Trivedi MK, Tallapragada RM, Branton A, Trivedi D, Nayak G, Latiyal O, Jana S (2015) Potential impact of biofield treatment on atomic and physical characteristics of magnesium. Vitam Miner 3: 129.

[27] Trivedi MK, Branton A, Trivedi D, Nayak G, Sethi KK, Jana S (2016) Gas chromatography-mass spectrometry based isotopic abundance ratio analysis of biofield energy treated methyl-2-napthylether (Nerolin). American Journal of Physical Chemistry 5: 80-86.

[28] Trivedi MK, Branton A, Trivedi D, Nayak G, Panda P, Jana S (2016) Gas chromatography-mass spectrometric analysis of isotopic abundance of ${ }^{13} \mathrm{C},{ }^{2} \mathrm{H}$, and ${ }^{18} \mathrm{O}$ in biofield energy treated $p$-tertiary butylphenol (PTBP). American Journal of Chemical Engineering 4: 78-86.

[29] Trivedi MK, Branton A, Trivedi D, Nayak G, Mondal SC, Jana S (2015) Evaluation of biochemical marker - glutathione and DNA fingerprinting of biofield energy treated Oryza sativa. American Journal of BioScience 3: 243-248.

[30] Trivedi MK, Branton A, Trivedi D, Nayak G, Gangwar M, Jana S (2016) Molecular analysis of biofield treated eggplant and watermelon crops. Adv Crop Sci Tech 4: 208.

[31] Trivedi MK, Tallapragada RM, Branton A, Trivedi D, Nayak G, Latiyal O, Jana S (2015) Physical, atomic and thermal properties of biofield treated lithium powder. J Adv Chem Eng 5: 136.

[32] Trivedi MK, Tallapragada RM, Branton A, Trivedi D, Nayak G, Latiyal O, Jana S (2015) Evaluation of biofield energy treatment on physical and thermal characteristics of selenium powder. Journal of Food and Nutrition Sciences 3: 223-228.

[33] Trivedi MK, Tallapragada RM, Branton A, Trivedi D, Nayak G, Mishra RK, Latiyal O, Jana S (2015) Physicochemical characterization of biofield energy treated calcium carbonate powder. American Journal of Health Research 3: 368-375.

[34] Ladics GS (2007) Primary immune response to sheep red blood cells (SRBC) as the conventional T-cell dependent antibody response (TDAR) test. J Immunotoxicol 4: 149-152.

[35] King EJ, Armstrong AR (1934) Estimation of alkaline phosphatase. Canad Med Assoc J 311: 152-156.

[36] Folch J, Lees M, Sloane Stanley GH (1957) A simple method for the isolation and purification of total lipids from animal tissue. J Biol Chem 226: 497-509.

[37] Devasagayam TPA, Tarachand U (1987) Decreased lipid peroxidation in the rat kidney during gestation. Biochem Biophys Res Commun 145: 134-138.

[38] Marklund S, Marklund G (1974) Involvement of superoxide anion radical in the autooxidation of pyrogallol and a convenient assay for superoxide dismutase. Eur J Biochem 47: 469-474.

[39] Sinha AK (1972) Colorimetric assay of catalase. Anal Biochem 47: 389-394.

[40] Malik F, Singh J, Khajuria A, Suri KA, Satti NK, Singh S, Kaul MK, Kumar A, Bhatia A, Qazi GN (2007) A standardized root extract of Withania somnifera and its major constituent withanolide-A elicit humoral and cell-mediated immune responses by up regulation of Th1-dominant polarization in BALB/c mice. Life Sci 80: 1525-1538.

[41] Spallholz JE, Stewart JR (1989) Advances in the role of minerals in immunobiology. Biol Trace Elem Res 19: 129151.

[42] Uppal SS, Verma S, Dhot PS (2003) Normal values of CD4 and CD8 lymphocyte subsets in healthy indian adults and the effects of sex, age, ethnicity, and smoking. Cytometry B Clin Cytom 52: 32-36. 
[43] Mikolai J, Erlandsen A, Murison A, Brown KA, Gregory WL, Raman-Caplan P, Zwickey HL (2008) In vivo effects of ashwagandha (Withania somnifera) extract on the activation of lymphocytes. J Altern Complement Med 15: 423-430.

[44] Jung Y, Rothenberg ME (2014) Roles and regulation of gastrointestinal eosinophils in immunity and disease. J Immunol 193: 999-1005.

[45] Madhuri S, Pandey G, Khanna A, Shrivastav AB (2012) Effect of some herbal drugs on haematological profiles of rats. IRJP 3: 158-160.

[46] Durrani FR, Abidullah NC, Durrani Z, Akhtar S (2008) Hematological, biochemical, immunomodulatory and growth promoting effect of feed added wild mint (Mentha longifolia) in broiler chicks. Sarhad J Agric 24: 661-664.

[47] El Hendy HA, Yousef MI, Abo El-Naga NI (2001) Effect of dietary zinc deficiency on hematological and biochemical parameters and concentrations of zinc, copper, and iron in growing rats. Toxicology 167: 163-170.

[48] Alimohamady R, Aliarabi H, Bahari A, Dezfoulian AH (2013) Influence of different amounts and sources of selenium supplementation on performance, some blood parameters, and nutrient digestibility in lambs. Biol Trace Elem Res 154: 4554.

[49] Cinar V, Nizamlioglu M, Mogulkoc R, Baltaci AK (2007) Effects of magnesium supplementation on blood parameters of athletes at rest and after exercise. Biol Trace Elem Res 115: 205-212.

[50] Andallu B, Radhika B (2000) Hypoglycemic, diuretic and hypocholesterolemic effect of winter cherry (Withania somnifera, Dunal) root. Indian J Exp Biol 38: 607-609.

[51] Bunglavan SJ, Garg AK, Dass RS, Shrivastava S (2014) Effect of supplementation of different levels of selenium as nanoparticles/sodium selenite on blood biochemical profile and humoral immunity in male wistar rats. Vet World 7: 10751081 .

[52] Fox C, Ramsoomair D, Carter C (2001) Magnesium: Its proven and potential clinical significance. South Med J 94: 1195-1201.

[53] Payahoo L, Ostadrahimi A, Mobasseri M, Bishak YK, Farrin N, Jafarabadi MA, Mahluji S (2013) Effects of zinc supplementation on the anthropometric measurements, lipid profiles and fasting blood glucose in the healthy obese adults. Adv Pharm Bull 3: 161-165.
[54] Torres-Duran PV, Ferreira-Hermosillo A, Juarez-Oropeza MA, Elias-Viñas D, Verdugo-Diaz L (2007) Effects of whole body exposure to extremely low frequency electromagnetic fields (ELF-EMF) on serum and liver lipid levels, in the rat. Lipids Health Dis 6: 31 .

[55] Giannini EG, Testa R, Savarino V (2005) Liver enzyme alteration: A guide for clinicians. CMAJ 172: 367-379.

[56] Sidhu P, Garg ML, Dhawan DK (2005) Protective effects of zinc on oxidative stress enzymes in liver of protein-deficient rats. Drug Chem Toxicol 28: 211-230.

[57] El-Boshy ME, Risha EF, Abdelhamid FM, Mubarak MS, Hadda TB (2015) Protective effects of selenium against cadmium induced hematological disturbances, immunosuppressive, oxidative stress and hepatorenal damage in rats. J Trace Elem Med Biol 29: 104-110.

[58] Karandish M, Tamimi M, Shayesteh AA, Haghighizadeh MH, Jalali MT (2013) The effect of magnesium supplementation and weight loss on liver enzymes in patients with nonalcoholic fatty liver disease. J Res Med Sci 18: 573-579.

[59] Sabiba EP, Rasool M, Vedi M, Navaneethan D, Ravichander M, Parthasarathy P, Thella SR (2013) Hepatoprotective and antioxidant potential of Withania somnifera against paracetamol-induced liver damage in rats. Int J Pharm Pharm Sci 5: 648-651.

[60] Ambiye VR, Langade D, Dongre S, Aptikar P, Kulkarni M, Dongre A (2013) Clinical evaluation of the spermatogenic activity of the root extract of Ashwagandha (Withania somnifera) in oligospermic males: A Pilot study. Evid Based Complement Alternat Med 2013: 571420.

[61] Shafiei Neek, Gaeini AA, Choobineh S (2011) Effect of zinc and selenium supplementation on serum testosterone and plasma lactate in cyclist after an exhaustive exercise bout. Biol Trace Elem Res 144: 454-462.

[62] Cinar V, Polat Y, Baltaci AK, Mogulkoc R (2011) Effects of magnesium supplementation on testosterone levels of athletes and sedentary subjects at rest and after exhaustion. Biol Trace Elem Res 140: 18-23.

[63] Jana K, Samanta PK, Manna I, Ghosh P, Singh N, Khetan RP, Ray BR (2008) Protective effect of sodium selenite and zinc sulfate on intensive swimming-induced testicular gamatogenic and steroidogenic disorders in mature male rats. Appl Physiol Nutr Metab 33: 903-914.

[64] Karp SM, Koch TR (2006) Oxidative stress and antioxidants in inflammatory bowel disease. Dis Mon 52: 199-207. 